811.163.41:929 Маројевић P. 811.163.41'27

https://doi.org/10.18485/sj.2019.24.1.44

ДУШКО В. ПЕВУЉА*

Универзитет у Бањој Луци

Филолошки факултет
Оригинални научни рад Примљен: 11. 09. 2018. Прихваћен: 15. 01. 2019.

\title{
РАДМИЛО МАРОЈЕВИЋ О ОБНОВИ СРБИСТИКЕ
}

У раду се разматра допринос Радмила Маројевића обнови аутентичне српске националне филологије - србистике, и то кроз анализу његових књига из ове области, појединачних чланака и научних расправа те представљањем његовог доприноса организацији научних скупова из области српске филологије, покретању србистичких часописа и креирању програмских докумената обновљене србистике. Посебно је истакнут значај Маројевићве историјске, прекретничке књиге Ћирилища на раскрићу векова (1991). У раду се скреће пажња и на Маројевићево интересовање за статус српског језика у односу на друге словенске језике, на подручју упоредне граматике, гдје се србистика не обнавља него, радовима овога аутора, научно утемељује и шири опсег својих истраживачких компетенција. Истакнуто је да обновитељским напорима српских филолога овај дијахронијски аспект даје посебну снагу и снажно учвршћење. Поменут је и Маројевићев рад на подручју српске текстологије, гдје се издвајају његова критичка издања и текстолошка читања Његошевих дјела Горски вијенац, Луча микрокозма и Биљежница.

Кључне ријечи: Радмило Маројевић, обнова србистике, Вук Караџић, Петар II Петровић-Његош, упоредна граматика, српски језик, славистика.

1. Од свог конституисања (у првим деценијама деветнаестог вијека) па до данас, у двовјековном историјском кретању, српска национална филологија је у знаку специфичних путева и странпутица. Њен утемељивач, Вук Караџић,

\footnotetext{
*duskopevulja@gmail.com

** Рад писан за зборник посвећен професору Радмилу Маројевићу (Српски језик XXIII).
} 
једновремено је и њено најзнатније име. Заснивању и афирмацији србистике крупне прилоге и значајне доприносе дали су водећи слависти прве половине деветнаестог вијека: Јозеф Добровски, Павел Јозеф Шафарик, Јернеј Копитар и Франц Миклошић. Конституисање србистике као дисциплине која се на научним основама бави српским народом, посебно је важно због тога што се временски подудара са Српском револуцијом и напорима за обнављање српске државе. Трајање србистике као доминантне српске филолошке парадигме може се везати за постојање самосталне српске државе. Својим дјелом и укупним радом на више планова велике доприносе србистици дали су неки од најистакнутијих представника српске научне мисли: Ђуро Даничић, Стојан Новаковић, Љубомир Стојановић, Павле Поповић, Јован Скерлић, Тихомир Остојић и бројни други. Међу њима и они који су били југословенски оријентисани, који су судбину сопственог народа видјели у заједници са другим сусједним и блиским јужнословенским народима.

Платформа југословенства на којој су настале обје југлословенске државе није се заснивала на србистици него на сербокроатистици, чији је утемељивач био највећи хрватски филолог Ватрослав Јагић. Важан замајац сербокроатистици, која је номинално словила и као српска филологија, дао је истакнути Вуков сљедбеник Ђуро Даничић, аутор знамените књиге Pam за српски језик и правопис (1847) и расправе „Разлика између језика Српскога и Хрватског" (1857). Међутим, овај српски филолог један је и од утемељивача сербокроатистике. Након пресељења у Загреб, гдје је постављен за секретара Југославенске академије знаности и умјетности он је пристао на преименовање српског језика и почео заступати Јагићеву сербокроатистичку филолошку концепцију (Милосављевић 2002а: 286-287). Преименовању српског језика, коме је својим ауторитетом легитимитет давао Даничић, оштро се супротставио пјесник Лаза Костић који је, не оспоравајући Даничићево знање и углед, назив језика српски или хрватски окарактерисао као „најсакатији од свих дуализама" (Милосављевић 2002а: 313) сматрајући га Даничићевим политичким а не научним гестом. У првој југословенској држави, која је настала на српским војничким побједама и огромним страдањима, српска вуковска филологија није фаворизована, али није програмски ни потискивана. На примјер, чувена књижевноисторијска синтеза Павла Поповића Преглед српске књижевности (1909), у којој је дубровачкој књижевности, као интегралном дијелу српске књижевне баштине, посвећено највише простора, измећу два свјетска рата објављена је у више издања. Сербокроатистика се безусловно, инструментима државе и ауторитетом званичних научних и културних институција у другој Југославији намеће као једина филолошка платформа. Увидом у садржину једног текста и концепцију једне књижевне едиције - да се само то нагласимо овом приликом - могу се сагледати кључна одређења те платформе. Текст је познат под насловом „Закључци Новосадског договора” (1954), а едиција под 
називом Српска кюижевност у сто кюига. У првој реченици „Закључака” српски језик се именује као српскохрватски, док се у првом закључку износи став који нема научно упориште и оправдање: „Народни језик Срба, Хрвата и Црногораца један је језик” (Милосављевић 2002a: 447). Чувена едиција Српска къижсевност у сто књига, супротно традицији дотадашњег представљања српске књижевности, најзначајнијим књижевноисторијским синтезама и најугледнијим књижевним историчарима, дубровачку књижевност не представља као саставни дио српске књижевне традиције (Певуља 2013: 21-22) .

2. Распадом/разбијањем друге југословенске државне заједнице престала је да постоји и филолошка парадигма на којој је она почивала. Српске културне и научне институције тај моменат нису искористиле као импулс за повратак властитој филолошкој традицији. Иако је језику српског народа враћен његов стварни назив, поново је именован као српски језик, на бројним другим научним и културним пољима, затим у раду најауторитативнијих националних институција, истрајавало се на сербокроатистичким ставовима и схватањима. У таквим околностима обнова вуковске србистике, истинске српске филологије, наметнула се као императиван задатак од научног али и од суштинског националног значаја. Властиту филологију нису обновиле српске институције нити истакнути појединци који су били у њиховом саставу, већ поједини српски филолози (лингвисти, проучавоаци књижевности, значајни писци и културни посленици). Један од најистакнутијих међу њима јесте Радмило Маројевић, угледни лингвиста богатог и разноврсног научног опуса, познавлац више лингивистици сродних научних дисциплина те стваралац импресивне радне енергије. У процесу обнове србистике, али и у српској филолошкој традицији уопште, књига Радмила Маројевића Ћирилица на раскрићу векова (1991) има историјску вриједност, прекретнички значај, једновремено обновитељски и утемељитески карактер. Састављена од публицистичких текстова који су објављивани у периоду од 1988. до 1991. године, књига на магистралан начин обједињује научну процедуру и научнопопулризовани начин презентовања резултата научних истраживања. Мирни и уједначени тон научне елаборације повремено смјењује експлицитна заоштреност публицистичке полемичности, у којој Маројевић није неодмјерен и склон брзом ефекту маниром поједностављивања саопштавања. Напротив, он је разложан, чињенички утемељен и опсервацијама неумољиво надмоћан. И када је оштар према опонентима, сјечиво његових полемичких ставова почива на снажним аргументима и увјерљивим разлозима. Од сличног типа хибридних текстова састављена је и Маројевићева књига Нови Рат за српски језик и правопис (2001), с том разликом што је импулс полемичности садржан већ у њеном наслову. Поред двије наведене, србистици, њеној обнови и заснивању, припадају још двије књиге Радмила Маројевића: Српски језик данас (2000) и Српска политика о етносу, језику, книжевном стандарду и писму (2011). 
3. Велики допринос Радмила Маројевића обнови србистике сагледаћемо на два начина: представљањем његовог рада у матици самог скоро тродеценијског процеса обнове и анализом његовог непосредног научног рада на плану повратка темељима националне филологије ${ }^{1}$.

4. Објављивање књиге Радмила Маројевића Ћирилища на раскрићу векова, 1991. године, треба сматрати као стварни почетак поновног конституисања истинске српске филологије (Певуља 2013: 328). У току читавог процеса обнове србистике објављено је неколико десетина значајних књига, које су из више истраживачких перспектива допринијеле поновном конституисању и развијању националне филологије. У најранијој, утемељитељској фази обнове, поред Маројевићевих, треба посебно издвојити књиге Петра Милосављевића: Српска књижевност и српски национални програм (1995), Систем српске къижевности (1996) и Срби и њихов језик (1997) те Милоша Ковачевића: У одбрану језика српскога (1997) и У одбрану језика српскога - и даље (1999). Радмило Маројевић активно учествује у креирању и организовању научних скупова који тематизују и проблематизују питања обнове србистике. Један од првих таквих скупова одржан је у Новом Саду (октобра 1996. године) под називом „Руски језик: српски језик - русистика: србистика”. Организатор овога скупа, Маројевић сматра да је управо на њему иницирана идеја о нужности занављања националне филологије. Његова аргументација изложена том приликом је научна (лингвистичка), са истовременим инсистирањем на славистичким, општеважећим критеријумима: „Ако је русистика наука која се бави руским језиком, онда и наука која се бави српским језиком (књижевношћу, писмом, културом) у систему научних дисциплина мора добити одговарајуће име, а то име може бити само - србистика" (Маројевић 2007: 34-35). Услиједили су затим сљедећи скупови на којима Маројевић иступа са запаженим рефератима: „Дело Петра Милосављевића и србистика” (Косовска Миторовица и Грачаница, октобар 2002. године); „Српско питање и србистика” (Нови Сад, новембар 2007. године); „Срби муслиманске вјероисповијести” (Београд, 2012. године); „Србистика и стране филологије” (Бањалука, мај 2015. године). Научни скупови у Новом Саду и Бањалуци разликују се од других симпозијума по томе што су резултирали интегралним текстовима/закључцима. Новосадски „Закључцима новосадског скупа Српско питање и србистика” (Закључици 2007:

\footnotetext{
${ }^{1}$ Хрестоматијом Обнова србистике, у коју смо уврстили по пет репрезентативних текстова Петра Милосављевића, Радмила Маројевића и Милоша Ковачевића, настојали смо да представимо кључне моменте у процесу обнове националне филологије. Не може се оспорити да је ријеч о тројици аутора који су на том плану били најактивнији и највише урадили. Међутим, објављујући у књизи радове Милосављевића, Маројевића и Ковачевића нисмо имали намјеру да маргинализујемо значај и допринос бројних других српских научника у обнови србистике. Поред уводне и закључне студије, хрестоматија Обнова србистике саджи још и расправу Вука Караџића „Срби сви и свуда” те Слово о српском језику. Овим текстовима смо намијенили - суштински и симболички - пролошку односно епилошку улогу (Певуља 2013).
} 
143-146), бањалучки „Основним начелима и препорукама о српском језику, књижевности и култури” (Основна начела 2014/2015). Ипак, најважнији заједнички текст о обнови србистике, чији је Маројевић један од најзначајнијих аутора, јесте Слово о српском језику, објављено у августу 1998. године (Слово $1998)^{2}$. Обједињујући напоре српских филолога из различитих српских центара, Петар Милосављевић је у октобру мјесецу 1997. године основао Покрет за обнову србистике. Поред научних скупова и бројних других догађаја које је покрет организовао, треба посебно издвојити часопис Cрбистика/Serbica, чији први број је објављен 1998. године. Упркос добро осмишљеној концепцији и десетинама разноврсних и вриједних радова, изашло је свега пет бројева овог гласила. Посљедњи број (1-2/1999.) штампан је 2002. године; у наредним годинама, у форми различитих зборника (са ознаком ванредни број), часопис је публикован још неколико пута, али без континуираног ритма излажења. Радмило Маројевић је био у Савету часописа, а у броју 2-3/1998, на уводном мјесту, објавио је један од својих најважнијих текстова под насловом „Српски језик и славистика", релевантан како за обнову тако и за утемељење србистике, назначавање њених будућих истраживачких перспектива.

${ }^{2}$ Поред овдје наведених активности Радмила Маројевића треба поменути и његово учешће на бројним трибинама о србистичкој проблематици, одржана предавања и разговоре објављене у више новина и књижевних часописа. Један од најзапаженијих и по импликацијама најдалекосежнијих његових јавних иступа десио се на Другом конгресу српских интелектуалаца, одржаном у Београду 1994. године. Овај догађај и Маројевићев гест детаљно је описао Петар Милосављевић: „Показало се, већ у току заседања, да је овај конгрес са мноштвом учесника и поднетих реферата и саопштења (60) имао и једну посебну сврху. Огромном броју окупљених српских интелектуалаца требало је да потврди исправност опредељења да се српски књижевни језик стандардизује на основи екавице. Јер, у том тренутку није било нити је могло бити ауторитативнијег тела од оваквог конгреса које би могло да изрекне такву потврду Уколико би овако моћан скуп интелектуалаца потврдио став о екавици као српском језичком стандарду, посао би био обављен. Десило се, међутим, нешто непредвиђено. Реферат Павла Ивића, који је сасвим јасно ишао у смеру наметања екавице као језичког стандарда за српски народ, наишао је на полемичку реакцију прво русисте Радмила Маројевића, а затим и других учесника скупа. Тако се десило да је у први план Конгреса избила несагласност око стандардизације српског језика [...]. Концепција о српском језику коју је на конгресу заступао Радмило маројевић најпре је изложена у његовој књизи Ћирилица на раскрићу векова (1991). Она је сагласна са концепцијом Вука Караџића, Стојана Новаковића, Љубомира Стојановића, па и самог Ивића из књиге Српски народ и његов језик (1971). Маројевићева концепција је изникла из српске филолошке традиције [...]. Професор Маројевић има неоспорне заслуге што је ту концепцију у пресудном тренутку обновио и поткрепио речима и аргументима; показао се на делу и као одговоран научник и као одговорно политичко биће" (Милосављевић 2010: 136-137). Главни дио Маројевићевог полемичког иступа на Другом конгресу српских интелектуалаца гласи: „Овде морам да кажем да овакво постављање питања које је по среди бити или не бити српског културног јединства ако се успостави један изговор, екавски или ијекавски изговор - нема никаквог ни лингвистичког ни културноисторијског оправдања. То је једно потпуно маргинално питање. Од тога да ли ће Срби из Републике Српске, из Српске Крајине и Црне Горе писати званично нама у Београд на ијекавици и да ли ће чак у овим земљама уџбеници бити на ијекавици - то никаквог значаја нема за овај наш данашњи тренутак. Зато ме, заправо, веома много збуњује овај предлог и хитња с којом је он сачињен” (Маројевић 2007: 191) 
5. Темељи за испитивање етничке и културне самосвијести српског народа су, према Маројевићу, дјело највећег српског филолога и опус највећег српског пјесника. У разматрању филолошких питања дјело и допринос Вука Караџића су неупитни и не захтијевају било каква објашњења. Занимљиво је Маројевићево маркирање филолошке важности Његошевог дјела: „Ми полазимо од тога да велики песник може да буде од већег значаја за реконструкцију етничке историје и историјске судбине једног народа и културе него томови званичних лингвиста и историачара и целе библиотеке дежурних социолингвиста" (Маројевић 1991: 7).

Теоријски и методолошки изграђен и посвећен научник, Маројевић сматра да обнови србистике треба приступити након дефинисања релевантног научног концепта. У том смислу он наглашава да лингвистичка, као фундаментално хуманистичка истраживања нужно морају превазилазити оквире ове дисциплине и користити се резултатима других наука (етнолингвистике, социолингвистике, историје, етнологије, политикологије), јер се све оне у оваквом интердисциплинарном спрегу и методолошки добро заснованом приступу могу сматрати „помоћним лингвистичким наукама” (Маројевић 1991: 6). Драгоцјено је ауторово тумачење социолингвистике која је све више у служби идеолошких и политичких пројекција (нарочито у домену језичке политике), што је нарочито дошло до изражаја у посљедње три деценије на бившем југословенском ареалу. Прецизирајући ово запажање Маројевић каже: „[...] социолингвистика као наука је могућа само ако истраживање задовољава најстроже лингвистичке критеријуме, уз поштовање методологије лингвистичких и методологије социолошких наука" (Маројевић 1991: 6).

Након скоро једновјековног мијешања научних и идеолошко-политичких критеријума, Маројевић је свјестан да расправу о главним филолошким питањима, првенствено онима из сфере лингвистике и проучавања и представљања српске књижевности, треба започети полазним објашњењима и дистинктирањима. Једно од тих полазишта гласи: српски језик одређујуће је обиљежје српске етничке посебности. Српски књижевни језик и ћирилица као српско историјско писмо представљају „темеље националне културе”. Етничка и културна свијест чине „две стране, две историјске етапе, истог процеса"(Маројевић 1991: 15).

Књижевни (стандардни) језик који је називан српскохрватски, хрватскосрпски, хрватски или српски језик, затим хрватски, босански, бошњачки и црногорски, ,је књижевни језик створен на основи српског народног језика, па је његово једино исправно име: српски књижевни језик". Маројевић указује на разлике између српског (штокавског) и хрватског (чакавског) језика: „Српски (штокавски) и хрватски (кајкавски) били су посебни дијалекти већ у позној фази прасловенског језика. Српски и хрватски се чак ни генетски не 
своде на један језик или дијалект. Полазећи од ових неоспорних чињеница о језичкој и етничкој посебности српске и хрватске компоненте, ми не одричемо постојање дуготрајног раздобља паралелног развоја штокавског и чакавског дијалекта (језика), њиховог међусобног језичког утицаја, па чак и неке врсте језичког савеза" (Маројевић 1991: 13).

За основицу српског књижевног језика Вук Караџић је изабрао новоштокавске ијекавске говоре, „средишњи српски дијалекат”, за који је речено да је најкарактеристичнији и најоригиналнији говор српског језика (Стојан Новаковић) те наш најпрогресивнији и најчистији дијалекат (Радосав Бошковић). Вук се у образложењима за избор овог дијалекта за основицу књижевног језика, руководио етнолошким, лингвистичким и књижевноисторијским моментима. Зато је важна и сљедећа Маројевићева констатација: „Треба истаћи да је екавска варијанта српског књижевног језика, чије је увођење у језички стандард образложио Стојан Новаковић, заснована на ијекавском, а не на својим матичним говорима: она је настала екавизацијом књижевног идиома источнохерцеговачког типа" (Маројевић: 2001: 7). Осјетљивом питању одређења етничких граница српског народа Вук Караџић је приступио крајње обазриво и одговорно, полазећи од „најужег, али етнички тачног одређења српског народа и етничких граница српског језика" (Маројевић 2001: 12). Изједначавајући српски језик са штокавским нарјечјем, он се није саглашавао са концепцијама великих слависта Јозефа Добровског и Павела Јозефа Шафарика.

Када је ријеч о писму као темељној препознатљивости сваке националне културе, српска ћирилица је српско национално писмо и знаковни израз српске културе: „Она је то била током читавог периода историјског трајања српског народа, од првих писаних споменика до данас" (Маројевић 1991: 15-16). Латиницу Маројевић сматра алтернативним писмом српског језика на којем је настала значајна писана традиција која је саставни дио српске културе.

6. Један од најважнијих текстова за једновремену обнову (на оним плановима на којима је то нужност) и утемељење (у оним доменима гдје је то неопходност) лингвистичке србистике јесте обимна студија Радмила Маројевића „Српски језик и славистика”. У дубинској дијахронијској перспективи, полазећи од реконструкције обиљежја српског дијалекта позног прасловенског језика, аутор србистичка питања, она која су погрешно интерпретирана и она која у српској науци уопште нису до тада озбиљно разматрана, сагледава у најширем и научно најрелевантнијем славистичком оквиру. Након описа типолошких особина српског дијалекта општесловенског језика, Маројевић испитује однос тог дијалекта према старословенском књижевном језику и закључује: „Старословенски књижевни језик створен је на периферним говорима (околина Солуна) српскословенског дијалекта позног прасловенског језика. То значи да је српски дијалекат његова језичка основа, а српски језик заједно са бугарским језиком и македонским говорима - његов насљедник” (Маројевић 
1998: 7). Дефинишући главна диференцијална својства српског језика, у односу на породицу словенских језика - наглашавајући при томе да српски као и сваки други језик има своје језичко језгро (које најистрајније чува главне типолошке црте) и своју периферију (у којој су те црте слабије изражен или су пред нестаноком), аутор се у наставку студије бави односом српског језика према прасловенском, затим према старословенском и, најзад, према својим регионалним варијантама: „Није довољно само дефинисати српски језик [...], потребно је одредити однос тог језика према његовој генетској основи [...], према словенским језицима са којима се налази у непосредном контакту [...], према његовим регионалним и конфесионалним варијантама и именима" (Маројевић 1998: 17). За савремену језичку ситуацију међу народима са јужнословенског простора, најважније је из ове перспективе освјетљавање односа кајкавског, чакавског и штокавског дијалекта (језика). Подробном анализом разлика између ових дијалеката (језика), Маројевић констатује: „Кајкавски чини типолошку и генетску цјелину са словеначким, а не са српским језиком. Хрватски језик (тзв. чакавски) не чини генетску цјелини ни са српским (тзв. штокавским), ни са словеначким (укључујући и тзв. кајкавски)" (Маројевић 1998: 21). У завршном дијелу студије „Српски језик и славистика” од посебне користи је ауторово класификовање књижевних језика српске културе (старословенски књижевни језик, латински језик као књижевни језик српске културе, српско-ћирилички књижевни језик раног средњег вијека, српско-латинички књижевни језик раног средњег вијека, српско-латинички књижевни језик позног средњег вијека, руски језик као књижевни језик српске култре, славеносрпски књижевни језик и савремени српски књижевни језик) и сажето али информативно описивање њихових специфичности.

7. Рад на критичким издањима и текстологији дјела настајалих на побројаним књижевним језицима српске културе Маројевић сматра једним од најважнијих задатка србистике и оним њеним подручјем на којем предстоје бројни послови од прворазредне националне важности. У више својих радова он је теоријски образложио природу текстолошких испитивања, а онда то потврдио истрајним бављењем дјелом највећег српског пјесника Петра Петровића Његоша. У предговору књизи Горски вијенаи: изворно читање, најављујући своје проучавање опуса великог пјесника, Маројевић констатује: „Дочекали смо 1997. годину потпуно неспремни. Немамо критичко издање Горског вијенца. Немамо критички обрађен збирни коментар Горског вијенща. Немамо описан стих Горског вијенща са становишта модерне версологије. Непотпуно је и фрагментарно изучен језик Његошевог пјесничког дјела. Немамо редовни библиографски попис радова из његошологије" (Маројевић 1999: 7). Несвакидашњом радном енергијом и научним компетенцијама које обухватају више комплементарних дисциплина, од момента када је исписао ове редове, Маројевић је евидентиране недостатке, додатно наглашене анафоричним по- 
нављањима, претворио у крупне резултате србистике и његошологије. Урадио је критичка издања и текстологију најгласовитијих Његошевих дјела, Горског вијениа (Његош 2005) и Луче микрокозма (Његош 2016) те пјесникове Биљежнице (Његош 2017)). Тако су створене претпоставке за тумачење Његошевих пјесничких дјела са ослањањем на знања која ранији истраживачи нису имали на располагању (Певуља 2015: 140-144).

8. Књигама и појединачним радовима - насталим у посљедњих тридесет година - посвећеним обнови и заснивању српске националне филологије, Радмило Маројевић се сврстао у ред најзначајнијих српских филолога од утемељења србистике до данас. У том своме раду Маројевић је исказао највишу научну свијест и одговорност према најважнијим питањима опстанка српског народа.

\section{ИЗВОРИ}

Слово 1998: „Слово о српском језику”, Србистика, број 2-3, Приштина: Покрет за обнову србистике, стр. 41-49.

Закључци 2008: „Закључци новосадског скупа Српско питање и србистика”, Српско питање и србистика, Бачка Паланка - Ваљево: Логос - Књиготворница Логос, стр. 143-146.

Основна начела 2014/2015: „Основна начела и препоруке о српском језику, књижевности и култури”, Крајина, бр. 3-4, Бањалука: Арт принт, стр. 3-8.

\section{ЛИТЕРАТУРА}

Маројевић 1991: Радмило Маројевић, Ћирилица на раскрићу векова, Горњи Милановац: Дечје новине - Београд: Српски фонд словенске писмености и словенских култура.

Маројевић 1998: Radmilo Marojević, Srpski jezik i slavistika, Србистика, број 2-3, Приштина: Покрет за обнову србистике, 5-40.

Маројевић 1999: Горски вијенач: изворно читање, Никшић: Јавно предузеће Центар за информативну дјелатност Никшићке новине - Београд: Унирекс.

Маројевић 2001: Радмило Маројевић, Нови Рат за српски језик и правопис, Београд: Требник - Подгорица: Унирекс - Бања Лука: Media centar Прелом. 
Маројевић 2007: Радмило Маројевић, Нема дубоких потреса, Српско питање и србистика: документи и коментари, Бачка Паланка - Ваљево: Логос - Књиготворница Логос, 191-192.

Маројевић 2008: Радмило Маројевић, Српски језик, србистика и славистика, Српско питање и србистика, Бачка Паланка - Ваљево: Логос - Књиготворница Логос, 33-39.

Милосављевић 2002: Петар Милосављевић, Увод у србистику, Косовска Митровица: Филозофски факултет у Косовској Митровици - Београд: Требник.

Милосављевић 2002а: Петар Молосављевић, Срби и ґихов језик, Косовска Митровица: Филозофски факултет у Косовској Митровици - Београд: Требник.

Милосављевић 2010: Петар Милосављевић, Обнова српског нациионалног програма, Београд - Грачаница: Матица српска у Дубровнику Мирослав - Логос.

Његош 2005: Петар II Петровић-Његош, Горски вијенаи (критичко издање и текстологија), редакција и коментар Радмило Маројевић, Подгорица: ЦИД.

Његош 2016: Петар II Петровић-Његош, Луча микрокозма (критичко издање и текстологија), редакција и коментар Радмило Маројевић, Подгорица: ЦИД - Цетиње: Narodni muzej Crne Gore.

Његош 2017: Петар II Петровић-Његош, Биљежница (критичко издање и текстологија), редакција и коментар Радмило Маројевић, Подгорица: ЦИД.

Певуља 2013: Душко Певуља, Обнова србистике, Бањалука: Народна и универзитетска библиотека Републике Српске.

Певуља 2015: Душко Певуља, Повратак србистици, Бањалука: Арт принт. 


\section{РАДМИЛО МАРОЕВИЧ ОБ ОБНОВЛЕНИИ СЕРБИСТИКИ}

\section{Резюме}

В работе рассматривается вклад Радмило Мароевича в обновление аутентичной сербской национальной филологии (сербистики) через анализ его книг по данной тематике, отдельных статей и научных трактатов. Помимо этого, описывается его вклад в организацию научных конференций по сербской филологии, открытие сербистических журналов и составление программных документов обновленной сербистики. Отдельно отмечается значимость исторической книги Мароевича «Кирилица на перекрестке веков» (1991), ставшей отправной точкой в обновлении сербистики. В работе уделяется внимание интересам Мароевича к статусу сербского языка по отношению к другим славянским языкам в рамках сопоставительной грамматики. Сербистика не обновляется, а научно утверждается работами данного автора, чем расширяется охват ее исследовательских возможностей. Подчеркивается, что данный диахронических аспект в значительной степени способствует усилиям обновления, прилагаемым сербскими филологами. Упоминается также деятельность Мароевича в области сербской текстологии: выделяются его критические издания и текстологические прочтения прозведений Негоша «Горный венец», «Луч микрокосма», «Записная книжка».

Ключевые слова: Радмило Мароевич, обновление сербистики, Вук Караджич, Петр Петрович Негош, сопоставительная грамматика, сербский язык, славистика.

Душко В. Певуля 